\title{
PENGEMBANGAN PERANGKAT PEMBELAJARA IPA MENGGUNAKAN MODEL KOOPERATIF TIPE STAD DENGAN STRATEGI TALKING CHIPS UNTUK MENINGKATKAN HASIL BELAJAR
}

\author{
Lukluk Rahmawati ${ }^{1)}$, Budi Jatmiko ${ }^{2)}$, Raharjo ${ }^{3)}$ \\ 1)Mahasiswa Program Pascasarjana, Program Studi Pendidikan Sains, Universitas Negeri Surabaya \\ 2), 3)Dosen Pascasarjana Prodi Pendidikan Sains Universitas Negeri Surabaya \\ E-mail:lukluk.rahmawati91@gmail.com
}

\begin{abstract}
The purpose of this research to produce science learning material by using cooperative learning model STAD and talking chips strategy that valid, practical, and effective to improve learning outcomes of junior high school student's. The development of learning material use the 4D model and was tested at junior high school students class VIII A, VIII C, and VIII F with One Group Pretest-Posttest Design. The data collection used observation method, test, and quetionnaires. Descriptive data analysis of quantitative-qualitative results are: (1) Learning material on terms of a valid category of: (a) Validation of the instruments very good category $(3,78)$, (b) Readability of book $(92,9 \%)$ and worksheets $(95,18 \%)$ are easier category for student's; (2) Learning material on terms of practical category in: (a) Feasibility of instruction good category, (b) Obstacles for learning can be overcome; (3) The learning material effectiveness on terms of: (a) The response of student's positively (96,3\%), (b) Student's activity is active category, (c) Student's learning achievement increased the average of N-Gain 0,71 with high category. The analysis results of statistic suggests that there is a difference between the learning outcomes before and after implementation of STAD cooperative models with talking chips strategy. The conclusion of this research that the model of cooperative learning STAD with talking chips strategy are eligible to improve learning achievement of junior high school student's. The implications of this research are becoming students more daring to express opinions and be able to improve student learning outcomes of knowledge competence.
\end{abstract}

Keyword: Cooperative learning model STAD, talking chips strategy, student's learning achievement

Abstrak: Penelitian ini bertujuan untuk menghasilkan perangkat pembelajaran IPA model kooperatif tipe STAD dengan strategi talking chips yang valid, praktis, dan efektif untuk meningkatkan hasil belajar siswa SMP. Pengembangan perangkat pembelajaran menggunakan model $4 D$ dan diujicobakan pada siswa SMP kelas VIII A, VIII C, dan VIII F dengan rancangan One Group Pretest-Posttest Design. Pengumpulan data menggunakan metode observasi, tes, dan angket. Analisis data secara deskriptif kuantitatif-kualitatif dengan hasil : (1) Kevalidan perangkat pembelajaran ditinjau dari: (a) Hasil validasi perangkat berkategori sangat valid $(3,78)$, (b) Keterbacaan BAS $(92,9 \%)$ dan LKS $(95,18 \%)$ berkategori mudah dipahami oleh siswa; (2) Kepraktisan perangkat pembelajaran ditinjau dari: (a) Keterlaksanaan RPP berkategori baik, (b) kendala-kendala selama pembelajaran dapat diatasi; (3) Keefektifan ditinjau dari: (a) Respon siswa positif (96,3\%), (b) Aktivitas siswa kategori aktif, (c) Hasil belajar siswa kompetensi pengetahuan meningkat dengan rata-rata $N$-Gain 0,71 berkategori tinggi. Hasil analisis uji statistik menyatakan bahwa terdapat perbedaan hasil belajar antara sebelum dan sesudah penerapan model kooperatif tipe STAD dengan strategi talking chips. Simpulan penelitian ini, bahwa perangkat pembelajaran IPA model kooperatif tipe STAD dengan strategi talking chips yang dikembangkan layak digunakan untuk meningkatkan hasil belajar siswa SMP. Implikasi penelitian ini adalah siswa menjadi lebih berani mengemukakan pendapat dan dapat meningkatkan hasil belajar siswa kompetensi pengetahuan.

Kata kunci: Kooperatif tipe STAD, strategi talking chips, hasil belajar

\section{PENDAHULUAN}

Tujuan pendidikan IPA menekankan pada pemahaman tentang alam sekitar beserta kekayaan yang dimilikinya yang perlu dilestarikan dalam perspektif biologi, fisika, dan kimia (Permendikbud, 2013). IPA berkaitan dengan cara mencari tahu tentang alam secara sistematis, sehingga IPA bukan hanya penguasaan kumpulan pengetahuan tetapi juga merupakan suatu proses penemuan (Permendiknas, 2014). Integrasi berbagai konsep dalam mata pelajaran IPA menggunakan pendekatan trans-disciplinarity di mana konsep-konsep disiplin ilmu berbaur dan/atau terkait dengan permasalahan-permasalahan yang dijumpai di sekitarnya. Kondisi tersebut menjadikan pembelajaran IPA sebagai pembelajaran yang kontekstual.

Kurikulum saat ini dikembangkan melalui pendekatan pembelajaran berpusat pada siswa (studentcentered learning), yang sesuai dengan paradigma pembelajaran abad 21 yang menekankan pada kecakapan berfikir dan belajar. Kecakapan-kecakapan 
yang dikembangkan diantaranya adalah kecakapan dalam memecahkan masalah, berpikir kritis, kolaborasi, dan berkomunikasi (BSNP, 2010). Kecakapankecakapan tersebut akan memberikan manfaat kepada siswa dalam kepentingannya mempersiapkan kehidupan yang lebih baik dan meningkatkan kemampuan kecakapan hidup khususnya keterampilan berkomunikasi dapat menunjang prestasi akademik mereka.

Hasil studi mengenai prestasi sains, posisi Indonesia masih berada di bawah standar internasional. Hal ini dibuktikan dari hasil studi TIMSS (Trends in International Mathematics and Science Study) dan PISA (Programme for International Student Assessment) menunjukkan bahwa pendidikan di Indonesia dalam bidang sains masih jauh tertinggal dari negara-negara lain.

Berdasarkan hasil observasi di SMPN 31 Surabaya menunjukkan bahwa kurikulum yang digunakan adalah kurikulum 2013. Ketuntasan klasikal hasil belajar kompetensi pengetahuan mata pelajaran IPA $<80 \%$. Menurut standar penilaian, ketuntasan klasikal seharusnya $85 \%$. Data tersebut menunjukkan bahwa masih ada sebagian siswa yang belum mampu mencapai KKM 67. Penggunaan berbagai model telah dilakukan oleh guru sebagai upaya untuk meningkatkan hasil belajar siswa. Namun, ada aspek yang kurang diperhatikan, yaitu kompetensi sikap sosial siswa yang secara tidak langsung akan berpengaruh terhadap hasil belajar kompetensi pengetahuan. Dari hasil observasi, diketahui bahwa siswa cenderung kurang komunikatif dalam kegiatan belajar mengajar, yaitu terlihat saat diskusi dan presentasi hasil kegiatan penyelidikan. Kompetensi sikap sosial yang perlu ditingkatkan dalam observasi ini adalah kompetensi sikap komunikasi. Dalam kegiatan diskusi kelas, kurang adanya keterampilan dalam menyampaikan/ menyajikan data hasil diskusi kelompok, yaitu siswa hanya mampu membaca data hasil percobaan. Masalah lain yaitu kurangnya pemerataan kesempatan untuk berkomunikasi dimana hanya beberapa siswa saja yang mendominasi diskusi kelas.

Solusi yang dapat dilakukan guru untuk mengatasi permasalahan adalah melakukan inovasi pembelajaran. Salah satunya menggunakan model pembelajaran dan strategi pembelajaran yang tepat. Keterampilan berkomunikasi dapat dilatihkan dengan berbagai cara, salah satunya dengan menerapkan model pembelajaran berbasis kerjasama antar individu untuk meningkatkan kompetensi interpersonal dan kehidupan sosial siswa, yaitu dalam proes pembelajaran tersebut melibatkan siswa secara aktif (student-centered learning) seperti yang diajarkan dalam cooperative learning atau belajar bersama (BSNP, 2010).
Pelaksanaannya perlu dengan strategi yang tepat, yaitu menggunakan strategi talking chips. Strategi talking chips adalah salah satu strategi dalam pelaksaannya lebih cocok bila dipadukan menggunakan model pembelajaran kooperatif tipe STAD karena strategi talking chips menyediakan beberapa kartu yang digunakan selama diskusi sehingga selain untuk meningkatkan hasil belajar kognitif, kooperatif tipe STAD dengan strategi talking chips merupakan model pembelajaran yang lebih mengutamakan pemerataan kesempatan dalam kelompok yang heterogen. Hal ini sesuai dengan pendapat Nur, dkk. (2008) bahwa tidak hanya unggul bagi membantu siswa memahami konsepkonsep yang sulit, tetapi berguna untuk menumbuhkan kemampuan bekerjasama, kreatif, berfikir kritis, dan siswa dapat terlibat aktif baik fisik maupun mental, misalnya siswa berani mengemukakan pendapat atau ide-idenya, melakukan diskusi baik antar siswa maupun guru.

Pembelajaran kooperatif tipe STAD dengan strategi talking chips dikembangkan oleh Spencer \& Kagan pada tahun 1992. Dalam pelaksanaannya, yaitu langkah pertama, guru menyampaikan tujuan pembelajaran yang ingin dicapai dan memotivasi siswa. Kedua, guru menyajikan informasi melalui kegiatan demonstrasi secara klasikal. Ketiga, guru mengorganisasikan siswa menjadi kelompok belajar dimana siswa bisa memikirkan dan menyelesaikan permasalahan. Langkah keempat, melalui kegiatan diskusi kelompok siswa dapat saling menguatkan materi dengan cara mengkomunikasikan hasil penyelidikan. Kegiatan talking chips, masing-masing anggota kelompok mendapat kesempatan untuk memberikan kontruksi mereka dan mendengarkan pandangan dan pemikiran anggota yang lain. Menurut Kagan (2000) dalam Mulyana (2011), dalam pelaksanaan talking chips setiap anggota kelompok diberi sejumlah kartu atau chips (biasanya dua sampai tiga kartu). Setiap kali salah seorang anggota kelompok menyampaikan pendapat dalam diskusi, ia harus meletakan satu kartunya. Setelah memperoleh pengetahuan dan keterampilan, langkah selanjutnya guru memberikan tes individual dimana masing-masing siswa tidak boleh saling membantu. Langkah terakhir, guru memberikan penghargaan pada kelompok berdasarkan perolehan nilai peningkatan dari skor dasar ke skor kuis.

Strategi ini menekankan pada proses pencarian pengetahuan daripada transfer pengetahuan, siswa dipandang sebagai subjek belajar yang perlu dilibatkan secara aktif dalam proses pembelajaran dengan memberikan kesempatan kepada siswa untuk menemukan konsep sendiri dan memecahkan masalah, guru hanyalah seorang fasilitator yang membimbing dan mengkoordinasikan kegiatan belajar siswa. Selain itu, masing-masing anggota kelompok

Pengembangan Perangkat Pembelajara IPA Menggunakan Model Kooperatif Tipe Stad dengan Strategi Talking Chips untuk... 
mendapat kesempatan untuk memberikan konstruksi mereka dan mendengarkan pandangan dan pemikiran anggota yang lain. Sehingga dengan strategi talking chips selain dapat memberikan kesempatan berpikir dan belajar juga dapat membuat siswa membiasakan sikap sosial berkomunikasi.

Menurut Hovland, Janis \& Kelley dalam Ulya (2011), komunikasi adalah suatu proses melalui seseorang (komunikator) menyampaikan stimulus (dalam bentuk kata-kata) dengan tujuan mengubah atau membentuk perilaku orang-orang lainnya. Dalam kata lain komunikasi adalah suatu proses interaksi antara satu pihak terhadap pihak lainnya untuk mencari data atau menyampaikan informasi yang kemudian disampaikan secara langsung ataupun tidak langsung. Keterampilan komunikasi yang dimaksud adalah keterampilan komunikasi ilmiah, yaitu keterampilan siswa dalam menyampaikan apa yang dipahami secara kontekstual sebagai indikator kepahaman siswa terhadap materi yang disampaikan secara lisan.

Berdasarkan analisis kompetensi dasar, salah satu materi pada siswa SMP kelas VIII KD 3.8 adalah memahami tekanan pada zat cair dan penerapannya dalam kehidupan sehari-hari untuk menjelaskan tekanan darah, difusi pada peristiwa respirasi, dan tekanan osmosis, pada materi tersebut siswa diharapkan mampu memahami konsep-konsep tekanan pada zat cair. Proses pembelajarannya dengan strategi talking chips, juga diharapkan siswa mampu melatihkan sikap sosialnya.

Berdasarkan uraian di atas peneliti mengangkat judul penelitian "Pengembangan Perangkat Pembelajaran IPA Menggunakan Model Kooperatif Tipe STAD dengan Strategi Talking Chips untuk Meningkatkan Hasil Belajar". Diharapkan melalui penelitian ini siswa dapat memahami materi dan hasil belajar siswa menjadi lebih baik.

\section{METODE PENELITIAN}

Penelitian ini merupakan jenis penelitian pengembangan, yaitu mengembangkan perangkat pembelajaran yang mengacu pada model pengembangan perangkat 4D (four $D$ model) yang dimodifikasi sesuai kebutuhan. Rancanngan pengembangan perangkat pembelajaran dalam penelitian ini adalah sebagai berikut:

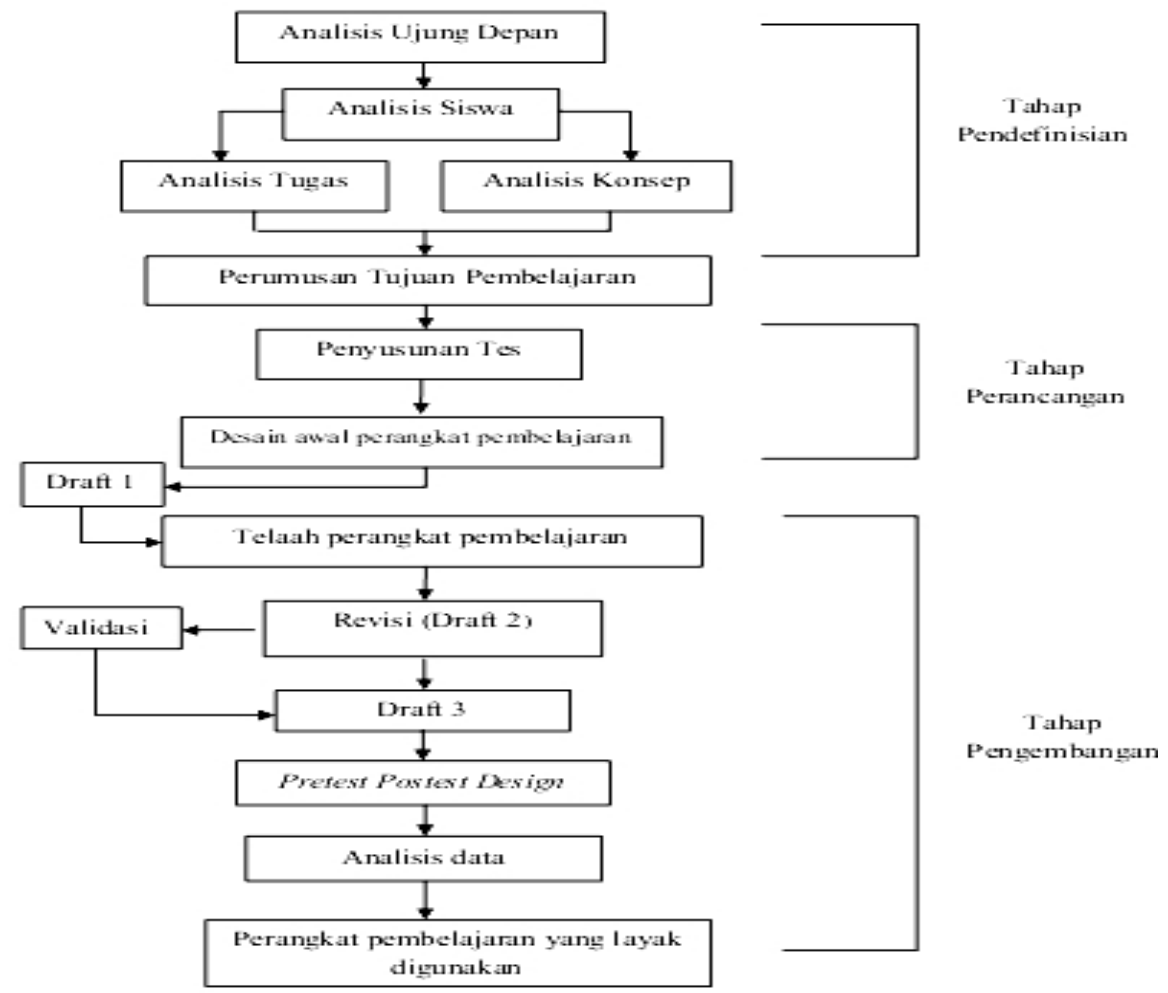

Gambar 1. Diagram Alur Tahap Pengembangan Perangkat (Diadaptasi dari, Ibrahim, 2002)

Ujicoba penelitian ini dilakukan pada siswa kelas VIII A, C, dan F SMP Negeri 31 Surabaya Tahun Pelajaran 2014-2015 dengan menggunakan rancangan penelitian One-Group Pretest-Postest Design. Instrumen penelitian ini di validasi oleh dua ahli pendidikan. Teknik pengambilan data pada penelitian ini adalah dengan observasi, tes dan angket. Materi yang dikembangkan dalam penelitian ini adalah tekanan zat cair dan penerapannya.

\section{HASIL DAN PEMBAHASAN}

Berikut hasil uji coba 2 perangkat pembelajaran yang telah dikembangkan dan diimplementasikan di SMP Negeri 31 Surabaya berupa, validasi perangkat, 
keterbacaan BAS (Buku Ajar Siswa) dan LKS (Lembar Kegiatan Siswa), keterlaksanaan pembelajaran, kendala selama kegiatan pembelajaran, aktivitas siswa, hasil belajar siswa, dan respon siswa.

\section{A. Kevalidan Perangkat Pembelajaran}

Validasi perangkat pembelajaran yang dikembangkan meliputi validasi oleh pakar dan keterbacaan BAS dan LKS, diperoleh hasil sebagai berikut: validitas RPP pada setiap aspek yang dinilai oleh dua validator diperoleh kategori sangat valid. Validitas BAS yang digunakan memenuhi kategori sangat valid. Validitas LKS yang meliputi aspek syarat didaktik, konstruksi, tulisan, dan gambar berkategori sangat valid. Hasil validitas THB pada aspek validitas isi serta bahasa dan penulisan soal berkategori sangat valid.

Persentase keterbacaan BAS dan LKS $>50 \%$, sehingga menyatakan bahwa BAS dan LKS berkategori mudah dipahami oleh siswa. Hal ini sesuai dengan pendapat Rothwell (dalam Sitepu, 2010) menyarankan agar buku ajar siswa mudah untuk dipahami. Selain itu, syarat model pengembangan buku menurut BSNP (2006) yang menyatakan bahwa buku yang baik adalah buku dengan keterbacaan yang tinggi dan mudah dipahami oleh siswa, sesuai dengan perkembangan psikososial siswa dan mampu membangkitkan belajar siswa.

\section{B. Kepraktisan Perangkat Pembelajaran}

Kepraktisan perangkat pembelajaran dalam penelitian ini ditinjau dari keterlaksanaan pembelajaran, dan kendala-kendala yang timbul selama kegiatan pembelajaran.

1. Keterlaksanaan Pembelajaran

Kegiatan pembelajaran dalam RPP yang dikembangkan meliputi kegiatan pendahuluan, inti, dan penutup. Kegiatan-kegiatan pembelajaran tersebut mencakup model, metode, dan sintak-sintak atau langkah-langkah pembelajaran. Sintak/langkah pembelajaran yang digunakan untuk mencapai tujuan pembelajaran yang telah ditetapkan mengacu pada model kooperatif tipe STAD dengan strategi talking chips. Berikut grafik hasil keterlaksanaan RPP.

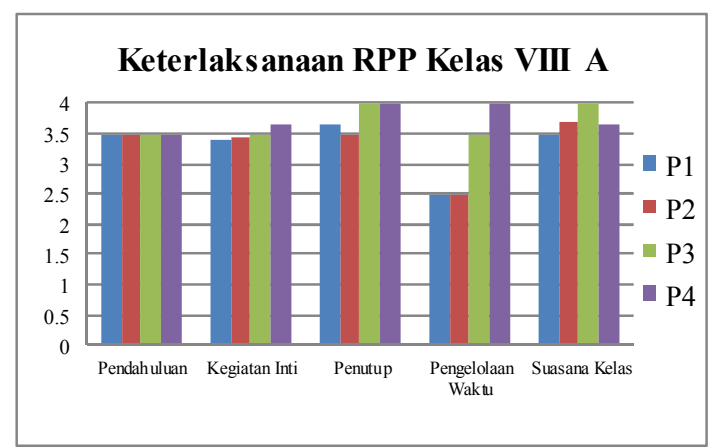

Gambar 2. Grafik Keterlaksanaan RPP Kelas VIII A

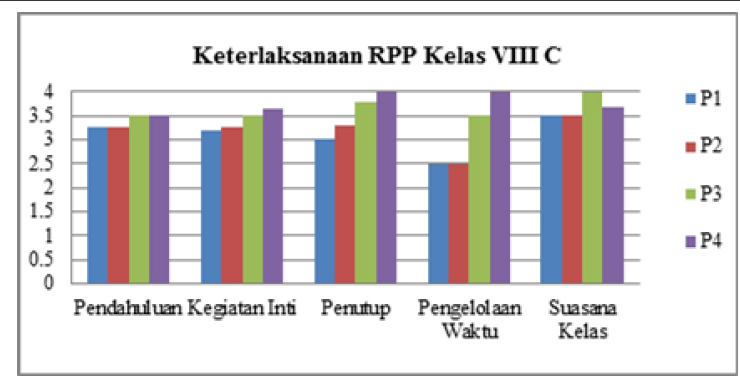

Gambar 3. Grafik Keterlaksanaan RPP Kelas VIII C

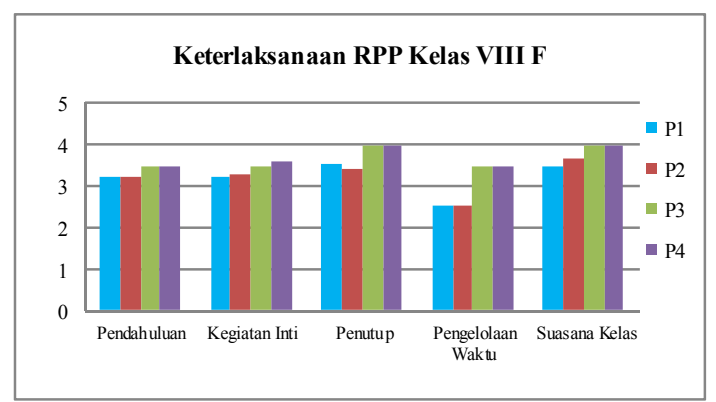

Gambar 4. Grafik Keterlaksanaan RPP Kelas VIII F

Selama empat kali pertemuan menyatakan bahwa keterlaksanaan RPP pada pertemuan pertama, kedua, ketiga, dan keempat dapat terlaksana dengan baik dan reliabel. Hal ini menunjukkan bahwa guru dalam melaksanaan pembelajaran menggunakan model kooperatif tipe STAD dengan strategi talking chips dapat terlaksana dengan baik.

2. Kendala Pembelajaran

Beberapa kendala yang dihadapi peneliti selama proses pembelajaran melalui model kooperatif tipe STAD dengan strategi talking chips diantaranya, (a) keterbatasan waktu, (b) siswa belum terbiasa merumuskan masalah dan hipotesis, dan (c) keterbatasan alat-alat laboratorium. Kendala-kendala tersebut dominan ditemukan pada pertemuan pertama sehingga dapat diminimalisir pada pertemuan berikutnya, dan dapat diatasi dengan beberapa solusi. Beberapa solusi untuk mengatasi Kendala-kendala tersebut diantaranya, (a) lebih memaksimalkan kegiatan yang lebih penting, (b) guru memberikan bimbingan dalam merumuskan masalah dan hipotesis, (c) guru memberikan alternatif penggunaan alat secara bergantian.

\section{Kefektifan Perangkat Pembelajaran}

Keefektifan perangkat pembelajaran yang dikembangkan ditinjau dari aktivitas siswa selama proses pembelajaran, hasil belajar siswa dari kompetensi sikap, pengetahuan dan keterampilan, serta respon siswa.

1. Aktivitas Siswa

Aktivitas yang dilakukan siswa selama kegiatan pembelajaran diantaranya membaca bahan ajar, 
melakukan percobaan, mencatat hasil pengamatan, bekerjasama dengan tim kelompok, berdiskusi tugas dengan teman sekelompok, mempresentasikan hasil kerja kelompok, bertanya, dan menyampaikan pendapat, mendengarkan penjelasan guru dan perilaku yang tidak relevan. Data keterlibatan aktif siswa sebesar $>85 \%$, sehingga dapat dikatakan bahwa model kooperatif tipe STAD dengan strategi talking chips yang direncanakan sudah berpusat pada siswa (student centered).

Nur (2008) menyatakan bahwa model koopertif tidak hanya unggul membantu siswa memahami konsep-konsep yang sulit, tetapi berguna untuk menumbuhkan kemampuan bekerjasama dan siswa dapat terlibat aktif baik fisik maupun mental, misalnya siswa berani mengemukakan pendapat atau ide-idenya, melakukan diskusi baik antar siswa maupun guru.

2. Respon Siswa

Respon siswa merupakan salah satu indikator keberhasilan pembelajaran yang dilakukan oleh guru. Respon siswa yang baik menunjukkan bahwa siswa senang mengikuti pembelajaran. Hasil respon siswa dalam mengikuti pembelajaran secara tidak langsung akan meningkatkan hasil belajar pengetahuan. Respon siswa terhadap komponen-komponen kegiatan pembelajaran diperoleh melalui angket yang diberikan kepada siswa.

Respon siswa menunjukkan bahwa siswa menyatakan menarik tentang materi/isi pelajaran, LKS, BAS, cara guru mengajar, dan suasana belajar. Ketiga kelas menyatakan bahwa komponen tentang materi/isi pelajaran, LKS, BAS, cara guru mengajar, dan suasana belajar baru bagi mereka. Siswa menyatakan mudah mengikuti komponen bahasa dalam BAS, materi buku, contoh soal, LKS, dan cara guru mengajar. Semua siswa menyatakan berminat apabila materi selanjutnya dan mata pelajaran lain diajarkan menggunakan pembelajaran seperti ini. Siswa menyatakan mudah/jelas tentang penjelasan guru saat kegiatan pembelajaran dan bimbingan guru saat melakukan percobaan. Siswa menyatakan mudah mengenai evaluasi pembelajaran.

Uraian di atas menunjukkan bahwa proses pembelajaran yang telah diikuti dapat dikatakan berpusat pada siswa. Gagne et.al (1988), menyatakan pembelajaran merupakan jembatan yang membantu siswa untuk membelajarkan siswa. Pernyataan Gagne et.al (1988) tersebut, sesuai dengan pandangan konstruktivis yaitu pembelajaran yang membelajarkan siswa, yakni menekankan pada partisifasi aktif siswa, dan memposisikan guru sebagai fasilitator (Westwood, 2008). Sebagai wujud dari pandangan konstruktivisme tersebut, dalam penelitian ini guru memfasilitasi siswa untuk belajar dengan menyediakan LKS sebagai panduan untuk melakukan pengukuran/pengamatan ataupun percobaan, dan melakukan diskusi. Melalui kegiatan tersebut, siswa diberikan kesempatan untuk berinteraksi dengan materi yang dipelajarinya melalui pengamatan atau praktikum, diskusi, dan memberikan kesempatan kepada siswa untuk memikirkan hasil pengamatan atau praktikum, dan hasil diskusinya, sehingga melalui kegiatan tersebut, diharapkan siswa dapat meningkatkan hasil belajar mereka dari materi yang telah mereka pelajari.

\section{Hasil Belajar Siswa}

Hasil belajar yang dinilai adalah kompetensi sikap spiritual, sikap sosial jujur dan percaya diri, kompetensi pengetahuan, dan kompetensi keterampilan. Sikap spiritual yang diamati selama pembelajaran berkategori baik dan sangat baik. Hal ini menunjukkan bahwa pembelajaran model kooperatif tipe STAD dengan strategi talking chips dapat mengembangkan sikap spiritual siswa meskipun tidak secara drastis karena hanya dilaksanakan selama empat kali pertemuan.

Sikap sosial yang diamati selama pembelajaran adalah jujur dan percaya diri. Sebagian besar siswa memperoleh nilai sikap sosial jujur dan percaya diri berkategori baik. Hal ini menunjukkan bahwa pembelajaran model kooperatif tipe STAD dengan strategi talking chips dapat mengembangkan sikap sosial jujur dan percaya diri siswa meskipun tidak secara drastis karena hanya dilaksanakan selama empat kali pertemuan.

Sikap adalah rencana atau kecenderungan untuk melakukan respon tertentu. Sikap dapat dibentuk sehingga terjadi perilaku atau tindakan yang diinginkan (Kemdikbud, 2013). Model pembelajaran kooperatif tipe STAD dengan strategi talking chips dapat mengembangkan sikap spiritual, sikap sosial jujur dan percaya diri, hal tersebut sesuai dengan pendapat Sudjana (2009) bahwa perubahan afektif merupakan suatu perubahan yang menyangkut sikap, nilai, perasaan, dan minat pada diri siswa. Sikap sosial dapat terbentuk karena adanya interaksi sosial. Interaksi sosial dapat terjadi karena hubungan saling mempengaruhi yaitu adanya hubungan timbal balik antara individu satu dengan yang lainnya sehingga mempengaruhi pola perilaku masing-masing individu.

Menurut Azwar (2013) beberapa faktor yang mempengaruhi pembentukan sikap adalah pengalaman pribadi, kebudayaan, orang lain yang dianggap penting, media massa, institusi atau lembaga pendidikan, dan faktor emosi dalam diri individu. Orang yang dianggap penting merupakan salah satu faktor dari pembentukan sikap yang sesuai dengan model yang diterapkan dalam pembelajaran ini, karena selama kegiatan pembelajaran siswa ditempatkan dalam kelompok kecil, teman sebaya sebagai orang yang dianggap bisa mempengaruhi pembentukan sikap sosial jujur dan percaya diri selama kegiatan pembelajaran. 
Selama kegiatan pembelajaran dengan strategi talking chips berlangsung, salah satu sumber belajar yang dipakai adalah kartu berwarna. Setiap siswa mendapatkan 4 buah kartu berwarna yang bisa digunakan selama kegiatan diskusi kelas. Penggunaan kartu berwarna sebagai salah satu sumber belajar dalam kegiatan pembelajaran dengan strategi talking chips memberikan pengaruh terhadap kompetensi sikap sosial percaya diri, yaitu dapat mengembangkan gairah siswa untuk ikut aktif selama diskusi kelas. Hal ini sesuai dengan pendapat Ibrahim (2010) bahwa salah satu fungsi sumber belajar adalah meningkatkan produktivitas pembelajaran dengan jalan mengurangi beban guru dalam menyajikan informasi, sehingga dapat lebih banyak membina dan mengembangkan gairah.

Ketuntasan hasil belajar dijadikan ukuran atau kriteria dalam mencapai suatu tujuan pendidikan. Tes dilakukan sebanyak dua kali, yaitu pretest dan posttest. Ada atau tidaknya perbedaan hasil belajar sebelum dan sesudah penerapan model kooperatif tipe STAD dengan strategi talking chips terhadap pembelajaran dapat diketahui melalui perhitungan uji-t berpasangan. Berdasarkan hasil perhitungan uji statistik dapat disimpulkan bahwa terdapat perbedaan hasil belajar yang signifikan antara sebelum dan sesudah penerapan model kooperatif tipe STAD dengan strategi talking chips pada materi tekanan zat cair. Selain itu, ternyata model kooperatif tipe STAD dengan strategi talking chips memiliki konsistensi terhadap peningkatan hasil belajar siswa. Jadi penerapan model pembelajaran kooperatif tipe STAD dengan strategi talking chips ini sangat efektif dilakukan dalam pembelajaran.

Keefektifan dalam pembelajaran tersebut diperkuat dengan penelitian sebelumnya yang dilakukan oleh Yanda (2013) menyatakan bahwa hasil belajar siswa yang menggunakan teknik talking chip lebih tinggi daripada hasil belajar siswa yang tidak menggunakan teknik talking chip. Penelitian lain dilakukan oleh Muliadinur (2014) menyimpulkan bahwa pengembangan perangkat pembelajaran IPA model kooperatif tipe STAD dengan strategi talking chips dapat meningkatkan hasil belajar pengetahuan sebesar $100 \%$. Penelitian Indinah (2014) menyimpulkan bahwa pengembangan perangkat pembelajaran IPA berorientasi pembelajaran kooperatif dapat melatihkan karakter jujur dan komunikatif ditunjukkan dengan hasil belajar kognitif peserta didik 97\% tuntas. Penelitian yang dilakukan Amirta (2010) menyatakan bahwa penggunaan model kooperatif teknik talking chip memberikan pengaruh yang signifikan terhadap hasil belajar. Penelitian oleh Syafryadin (2011) menyatakan bahwa penggunaan teknik talking chip selain dapat meningkatkan kemampuan berbicara juga mempengaruhi kemampuan kognitifnya.
Penelitian oleh Sunilawati (2013) menyatakan bahwa melalui model pembelajaran kooperatif tipe STAD siswa dapat memperoleh pengalaman hidup bersama melalui kerja sama dalam kelompok, mampu memberikan sikap positif dan percaya diri, karena dalam pembelajaran ada saling ketergantungan positif. Ketergantungan semacam ini selanjutnya akan memunculkan tanggung jawab individu terhadap kelompok dan keterampilan interpersonal dari setiap anggota kelompok. Sehingga, yang menarik dari pembelajaran ini adalah selain adanya peningkatan hasil belajar peserta didik juga mempunyai dampak pengiring seperti keterampilan sosial. Keterampilan sosial ini mutlak diperlukan dalam kehidupan keluarga, sekolah, masyarakat dan kehidupan bernegara.

Peningkatan hasil belajar kompetensi pengetahuan dapat dilihat dari $\mathrm{N}$-gain dengan kategori tinggi (Hake, 1999). Peningkatan yang ditunjukkan oleh hasil analisis dengan menggunakan $\mathrm{N}$-gain ini menunjukkan tentang penerapan dari pengembangan perangkat pembelajaran model kooperatif tipe STAD dengan strategi talking chips efektif dalam meningkatkan hasil belajar siswa pada materi tekanan zat cair dan penerapannya. Hal ini sesuai dengan pendapat Sudjana (2009), yang menyatakan bahwa suatu tujuan pembelajaran dapat tercapai apabila siswa sudah memahami belajar dengan diiringi oleh perubahan tingkah laku yang lebih baik lagi. Nur (2008) menyatakan bahwa interaksi sosial dengan teman lain akan membantu terbentuknya ide baru dan memperkaya perkembangan intelektual siswa. Hal ini dibuktikan dengan adanya peningkatan hasil belajar siswa, selama kegiatan pembelajaran siswa belajar dan bekerja sama dalam kelompok.

Hasil belajar kompetensi keterampilan menunjukkan bahwa siswa mengalami peningkatan pada pertemuan keempat, di mana rata-rata nilai siswa mengalami peningkatan. Hal ini mengindikasikan bahwa model kooperatif tipe STAD dengan strategi talking chips selain dapat meningkatkan hasil belajar pengetahuan juga dapat meningkatkan hasil belajar keterampilan, terutama keterampilan dalam menggunakan alat.

Berdasarkan analisis data validasi perangkat berkategori sangat valid, keterbacaan BAS dan LKS yang tinggi, keterlaksanaan RPP yang baik, beberapa kendala yang muncul dapat diatasi, siswa yang aktif selama kegiatan pembelajaran, respon siswa positif terhadap pembelajaran, beberapa hal tersebut mendukung adanya peningkatan hasil belajar siswa kompetensi pengetahuan. Selain hasil belajar kompetensi pengetahuan yang meningkat, hasil belajar kompetensi sikap spiritual dan sosial serta hasil belajar kompetensi keterampilan mengalami peningkatan di setiap pertemuannya. Hal ini menyatakan bahwa perangkat pembelajaran model kooperatif tipe STAD 
dengan strategi talking chips layak digunakan untuk meningkatkan hasil belajar siswa.

\section{SIMPULAN DAN SARAN}

\section{A. Simpulan}

Berdasarkan hasil analisis, diskusi, dan pembahasan, maka dapat dibuat kesimpulan bahwa perangkat pembelajaran model kooperatif tipe STAD dengan strategi talking chips yang dikembangkan untuk meningkatkan hasil belajar layak digunakan untuk meningkatkan hasil belajar siswa ditinjau dari kevalidan, kepraktisan, dan keefektifan.

\section{B. Saran}

Saran yang dapat dikemukakan oleh peneliti berdasarkan penelitian yang telah dilakukan adalah pembelajaran dengan model ini memerlukan pengelolaan waktu yang sebaik-baiknya, terutama harus mementingkan tahapan-tahapan tertentu (seperti diskusi kelas untuk meningkatkan kompetensi sikap berkomunikasi) yang lebih utama agar dapat berjalan sesuai dengan rencana.

\section{DAFTAR PUSTAKA}

Azwar, Saifuddin. (2013). Sikap Manusia Teori dan Pengukurannya. Yogyakarta: Pustaka Pelajar.

Badan Standar Nasional Pendidikan. 2010. Paradigma Pendidikan Nasional Abad XXI. Versi 1.

Depdiknas. (2006). Peraturan Menteri Pendidikan Nasional Nomor 22 Tahun 2006 tentang Standar Isi untuk Satuan Pendidikan Dasar dan Menengah. Jakarta: Depdiknas.

Gagne, Briggs \& Wager. (1988). Principles of Instructional Design. Toronto: Holt, Rinehart and Winstons, Inc.

Hake. (1999). Analyzing Change/Gain Scores. http://www.physics.indiana.edu/sdi/AnalyzingCh ange-Gain.pdf. Diunduh pada tanggal 10 Januari 2015.

Ibrahim, M. (2002). Pengembangan Perangkat Pembelajaran. Modul Disajikan pada Pelatihan Terintegrasi Berbasis Kompetensi Guru mata Pelajaran Biologi SLTP. Jakarta: Dirjen Dikdasmen Depdiknas.

Ibrahim, dkk. (2010). Dasar-dasar Proses Belajar Mengajar. Surabaya: Unesa University Press.

Indinah. (2014). Pembelajaran Kooperatif untuk Melatihkan Karakter Jujur, Komunikatif, dan Peduli Lingkungan. Tesis Magister Pendidikan. Universitas Negeri Surabaya.

Kagan, S. (1992) .The Structural Approach to Cooperative Learning. Education Leadership.

Kagan, S. (2010). Cooperative learning. San Clemente, CA: Kagan Publishing. Retrieved April 12nd. http://www.gdrc.org/kmgmt/clearn/methods.html. 1992, pp. 17.

Kemendikbud. (2013). KURIKULUM 2013. Jakarta: Badan Penelitian dan Pengembangan.
Lie, Anita. (2002). Cooperative Learning Mempraktikkan Cooperative Learning di Ruangruang Kelas. Jakarta: Gramedia.

Mashfufah. (2014). Pengembangan Perangkat Pembelajaran Biologi SMA Berorientasi Stategi Pembelajaran Think-Talk-Write untuk Meningkatkan Hasil Belajar dan Keterampilan Komunikasi Siswa Secara Lisan. Tesis Magister Pendidikan. Universitas Negeri Surabaya.

Muliadinur. (2014). Pengembangan Perangkat pembelajaran IPA Model Kooperatif Tipe STAD dengan Strategi Talking Chips untuk Meningkatkan Hasil Belajar Siswa. Tesis Magister Pendidikan. Universitas Negeri Surabaya.

Nur, Muhammad. (2008). Pembelajaran Kooperatif. Surabaya: PSMS UNESA.

Nur, Muhammad. \& Prima R. W. (2011). Pengajaran Berpusat Kepada Siswa dan Pendekatan Kontruktivis dalam Pengajaran. Surabaya: PSMS UNESA.

Permendikbud No 81A. (2013). Permendiknas Nomor $81 \mathrm{~A}$ Tahun 2013 Tentang Implementasi Kurikulum. Jakata:Kemdikbud.

Permendiknas. (2014). Permendiknas Nomor 58 Tahun 2014 Tentang Kurikulum 2013 Sekolah Menengah Pertamal Madrasah Tsanawiyah. Jakarta: Kemdikbud.

Sitepu. (2010). Keterbacaan. Diakses melalui (file:///D:/KULIAH\%20STEP\%202/KETERBAC AAN\%20_\%20B.\%20P.\%20Sitepu\%27s\%20Blo g.html) pada tanggal 20 Desember 2014.

Sudjana, Nana. (2009). Penilaian Hasil Proses Belajar Mengajar. Bandung: Remaja Rosdakarya.

Sunilawati, Ni M., Nyoman, Made. (2013). Pengaruh Model Pembelajaran Kooperatif Tipe STAD Terhadap Hasil Belajar Matematika Ditinjau Dari Kemampuan Numerik Siswa Kelas IV SD. e-Journal Program Pascasarjana Universitas Pendidikan Ganesha, Volume 3 Tahun 2013.

Syafryadin. (2011). The Use of Talking Chips Technique in Improving Student's Speaking Achievement. Indonesia University of Education. http://conference.pixel-online.net/...pdf/462SLA29. Diakses pada tanggal 15 Januari 2015.

Ulya, Himmatul. (2011). Hubungan Antara Kemampuan Berkomunikasi dengan Hasil Belajar Siswa Melalui Pembelajaran Kooperatif Tipe Jigsaw. Skripsi tidak dipublikasikan. Jakarta: UIN Syarif Hidayatullah Jakarta.

Yanda, A. B., Asrul, Yurnetti. 2013. Pengaruh Pengembangan Teknik Talking Chips Terhadap Hasil Belajar IPA Fisika Siswa Kelas VII SMPN 1 Jurai Kab. Pesisir Selatan. Pilar of Physics Education. Vol 1 April pp 97-103. 